\title{
原発性非小細胞肺癌完全切除例の 遠隔転移巣に対する外科治療成績の検討
}

羽隅 透*1, 佐藤 伸之 ${ }^{* 2}$, 太田伸一郎 ${ }^{* 3}$, 佐藤 雅美 ${ }^{* 4}$, 遠藤 千顕 ${ }^{* 5}$
近藤
丘 ${ }^{* 5}$, 鈴木 弘行*6, 大泉 弘幸*7, 千田 雅之*8
対馬 敬夫 ${ }^{* 9}$, 佐久間 勉 ${ }^{* 10}$, 斎藤 泰紀 ${ }^{* 1}$

要 旨

原発性非小細胞肺癌完全切除例の遠隔転移巣に対する外科治療後の予後を retrospectiveに検討した．対象は1998〜 2003年の期間に原発巣切除と同時あるいは異時性に一臟器のみに認められた数個以内の初遠隔転移巣とした。症例は 35例。転移部位は脳，肺，副腎，胸壁がそれぞれ17，10，6，2 例，原発巣病理病期（同時転移は考慮せず）は I, II, III 期がそれぞれ $16 ， 14 ， 5$ 例であった。転移巣術後の 2 年生存率は全体で $68.0 \%$ (中間生存期間 43.1 月), 原発巣病 理病期別では I， II，III 期がそれぞれ86.5，53.0，60.0\%であった。 pN 因子別比較では pN0，pN1-2がそれぞれ $82.9,50.3 \%$ と有意に $\mathrm{pN} 0$ 症例が予後良好であった，単発あるいは少数個の遠隔転移巣に対する外科治療の有効性は リンパ節転移を認めない原発肺癌早期症例において存在し，その予後の向上に寄与する可能性が示唆された.

索引用語：非小細胞肺癌, IV 期肺癌, 遠隔転移, 転移巣切除, オリゴメタスターシス non-small cell lung cancer, stage-IV lung cancer, distant metastasis, metastasectomy, oligometastasis

\section{はじめに}

StageIV 非小細胞肺癌あるいは術後遠隔転移症例に 対する治療は全身化学療法が主体となり, これに局所 制御を目的とした外科療法, 放射線療法が加わる。こ の際，局所療法が予後改善効果をもたらすか否かに関 するエビデンスは未だ明確ではなく，現時点では限ら れた脳転移症例においてのみ, その有効性が示されて いるにすぎない1)。しかし臨床治療においては時とし

\footnotetext{
*1仙台医療センター 呼吸器外科

$* 2$ 青森県立中央病院 呼吸器外科

*静岡県立総合病院 呼吸器外科

*4宮城県立がんセンター 呼吸器外科

*5東北大学加齢医学研究所 呼吸器再建研究分野

*6福島県立医科大学 第一外科

${ }^{* 7}$ 山形大学医学部 第二外科

*8太田西八内病院 呼吸器外科

*9弘前大学医学部 第一外科

$* 10$ 金沢医科大学 呼吸器外科

原稿受付 2006年 7 月11日

原稿採択 2006年 8 月29日
}

て脳以外の転移巣においても予後の向上を期待した外 科治療が試行されており，これらの中には少数ではあ るが長期生存例が存在するのも事実である2,3).

ここでは非小細胞肺癌完全切除例の中で同時・異時 性に発症した遠隔転移巣に対しても外科治療が行われ た症例を retrospectiveに集積して予後を調査し, 遠隔 転移巣切除の有効性に関して検討を行ったので報告す る。

\section{対象および方法}

対 象：適格基準を設け，関連多施設から症例を集 積した。適格条件は以下とした。(1)1998年 1 月から 2003年12月までの期間に原発性非小細胞肺癌に対する 完全切除およびその遠隔転移巣に対しても外科切除が 行われた症例である。ただ脳転移に対しては同等の 有効性4) 加定位放射線治療 (stereotactic radiosurgery, 以下 SRS) も可とする。(2)転移巣は原発巣切 除と同時あるいはその後の経過観察中に一臓器にのみ 
Table 1 Profiles of 35 patients undergoing metastasectomy.

\begin{tabular}{ll}
\hline Sex & Male/Female: 26/9 \\
\hline Age(y)a & $39-79$ (median: 63) \\
\hline ECOG-PS 0/1/2/3/4a & $16 / 8 / 1 / 0 / 1$ \\
\hline Site of metastasis & $<$ Synchronous $>$ \\
(methods of surgery) & Brain: 6 (craniotomy/SRS: 4/2) \\
\hline- Metachronous $>$ \\
& Brain: 11 (craniotomy/SRS: $5 / 6$ ) \\
& Lung: 10 (partial/completion: $9 / 1$ ) \\
& Adrenal gland: 6 (resection) \\
& Chest wall: 2 (resection) \\
\hline Histology & Ad/Sq/La: 26/7/2 \\
\hline No. of metastatic nodules & $1 / 2 / 3: 30 / 4 / 1$ \\
\hline Size of metastatic nodules (mm) & $5.0-100$ (median: 25) \\
\hline Interval for metastasis (months) & $5.3-41.1$ (median: 17.5$)$ \\
\hline Post-metastasectomy therapy & Yes/No: 15/20 \\
\hline Post-metastasectomy follow up (months) & $2.8-61.9$ (median: 23.8) \\
\hline
\end{tabular}

a At the time of metastasectomy, Ad: adenocarcinoma, Sq: squamous cell carcinoma, La: large cell carcinoma, SRS: stereotactic radiosurgery.

認められた数個以内の初遠隔転移巣とする。(3)切除さ れた遠隔転移巣は病理学的に原発巣からの転移との診 断を得ている(ただし脳転移は画像診断のみで可)。除 外条件として以下を設定した。1）原発巣切除が以下 (a) bの項目により，完全切除とは断定しえない，ある いは明らかに予後不良と判断される症例。（肺外臟器 に高度に浸潤, (b) multi-stationN2, bulky N2. 2 ) 5 年 以内の肺癌以外の重複癌を有する症例。3) 組織型が 同じ場合でも以下@(bの基準に合致した多発肺癌と考 え得る症例。 a) 上皮内癌成分を有するもの, (b) CT 画 像上 GGO 成分が優勢なもの.

予後解析：生存率は他病死を含む全死亡を死亡とす る Kaplan-Meiyer 法で算出し, 有意差検定には logrank 検定を用いた。群間のばらつき検討には $x 2$ 乗検

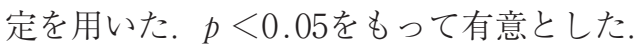

\section{結果}

関連10施設から35症例の登録があった（Table 1)。 男性26例，女性 9 例で，転移巣手術時の年齢は39〜 79 （中央值63）歳であった。転移部位および組織型は同 時性が脳のみで 6 例（腺癌： 4 , 扁平上皮癌 : 1 , 大 細胞癌：1), 異時性が肺10例 (同側/対側 ; $3 / 7$, 腺
癌：5, 扁平上皮癌： 5 ), 脳11例（全例腺癌）, 副腎 6 例 (腺癌: 5 , 大細胞癌 : 1 ), 胸壁 2 例 (腺癌 : 1 , 扁平上皮癌：1）であった。転移個数は脳転移にのみ 多発例を認めたが，それ以外は全て単発例であった。 原発巣手術から異時性転移を来すまでの期間は5.3〜 41.1力月 (中央值17.5), 転移巣手術からの観察期間は 2.8～61.9力月（中央值23.8) であった。転移巣手術は 脳 SRS 症例 8 例を除き, 全例において根治度 R0 1 の手術が行われた。転移巣手術に際し重篤な合併症お よび術死・在院死を認めなかった。術後補助療法は 15 症例に対して行われており, 全身化学療法13例, 開頭 術後全脳照射 2 例であった。

原発肺癌の pTN 因子内訳を Table 2 に示す。pT4 は pm1, pN2 は single-stationN2 によるものである. pN0, N1，N2 はそれぞれ19，13，3 例であった。肺転移10 例中 8 例が，また脳転移17例中 9 例が $\mathrm{pN} 0$ であり，副 腎転移 6 例中 5 例は pN1-2 であった。

転移巣術後に19例（54.3\%）が再発を来たし，内13 例が原病死した。再発詳細は肺転移例に 4 例（切除断 端再発： 1 , 同肺葉内転移： 1 , 他肺葉内転移： 1 , 骨転移：1），脳転移例に10例（新たな脳転移：7, 肝 転移：1, 骨転移：1, 筋転移：1), 副腎転移例に 
Table 2 Number of cases according to the pathologic TN factor.

\begin{tabular}{|c|c|c|c|c|c|c|c|c|c|}
\hline $\mathrm{pT}$ & \multicolumn{2}{|c|}{1} & \multicolumn{3}{|c|}{2} & \multicolumn{2}{|c|}{3} & \multicolumn{2}{|c|}{4} \\
\hline $\mathrm{pN}$ & 0 & 1 & 0 & 1 & 2 & 0 & 1 & 0 & 2 \\
\hline Lung & 4 & & 2 & & 1 & $1:$ & 1 & 1 & \\
\hline $\begin{array}{r}\text { Brain synchronous } \\
\text { metachronous }\end{array}$ & $\begin{array}{l}4 \\
2\end{array}$ & $\begin{array}{l}1 \\
4\end{array}$ & $\begin{array}{l}1 \\
2\end{array}$ & 2 & 1 & & & & \\
\hline Adrenal gland & & & & 4 & & 1 & & & 1 \\
\hline Chest wall & & & 1 & 1 & & & & & \\
\hline
\end{tabular}

4 例 (切除部局所再発 : 3 , 脳転移：1), 胸壁転移例 に 1 例 $($ 肺・骨転移)であった。 $\mathrm{pN}$ 因子別の再発は $\mathrm{pN} 0$ が47.4\% (9/19), pN1-2 が62.6\%（10/16） と再発率 上の有意差は認めなかったが，無再発 2 年生存率（お よび中間無再発生存期間）の比較では pN0 が56.8\% (25.5カ月), $\mathrm{pN} 1-2$ が38.3\%（16.4カ月）とリンパ 節転移を認めた症例はより早期に再発を来たす傾向に あった（Fig. 1)。

転移巣術後の 2 年生存率は全体で $68.0 \%$, 中間生存 期間（Median Survival Time, 以下 MST）は43.1カ月 であった。原発巣病理病期別（同時性遠隔転移は考慮 しないで評価）の 2 年生存率（Fig. 2) はI 期，II 期, III 期がそれぞれ $86.5,53.0,60.0 \%$ となり, さらに $\mathrm{pN}$ 因子で比較した場合 (Fig. 3)，2 年生存率および MST は pN0, pN1-2 でそれぞれ82.9\%（50.9カ月)，50.3\%

(35.4カ月）とリンパ節転移を認めない原発巣早期症 例が有意に予後良好であった $(p=0.04)$ 。転移巣術後 1000日以上の長期生存を認めたものは13例存在してお り, $\mathrm{pN} 0$ が 9 例（肺： 5 , 脳：4), pN1が 3 例(脳), $\mathrm{pN} 2$ が 1 例（肺）であった。

転移部位別の 2 年生存率は肺, 䐉, 副腎がそれぞれ 78.7，67.2，55.6\%であった。

原発巣手術から異時性転移巣手術までの期間別 2 年 生存率では 1 年未満 $(\mathrm{n}=9), \quad 1 \sim 2$ 年未満 $(\mathrm{n}=11)$, 2 年以上 $(\mathrm{n}=9)$ がそれぞれ $87.5 ， 47.7 ， 76.2 \%$ と 有意な傾向は認められなかった。脳転移例における術 式，発症別での比較では， 2 年生存率で開頭術/SRS が48.6/85.7\%，同時/異時が62.5/70.1\% と群間で有 意な差は存在しなかった。

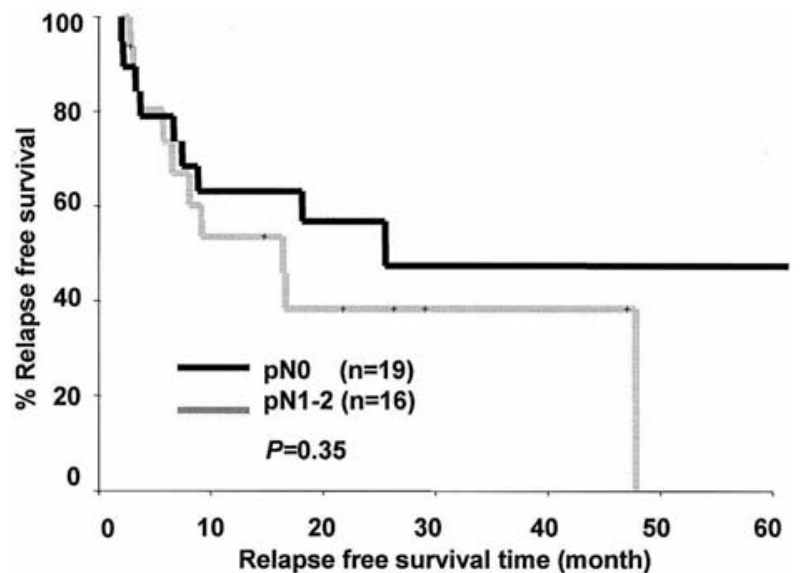

Fig. 1 Relapse-free survival rates from metastasectomy according to the pathologic $\mathrm{N}$ factor $(\mathrm{pN})$.

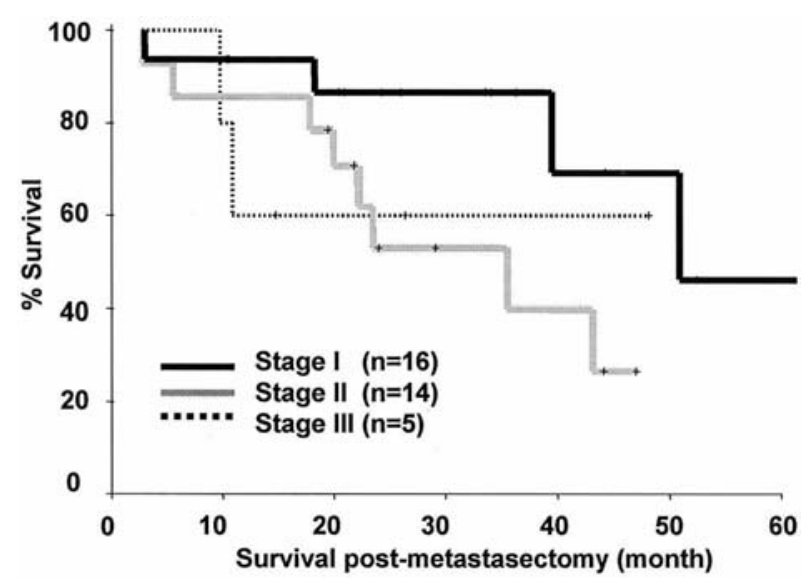

Fig. 2 Survival rates according to provisional pathologic stage, excluding the M factor.

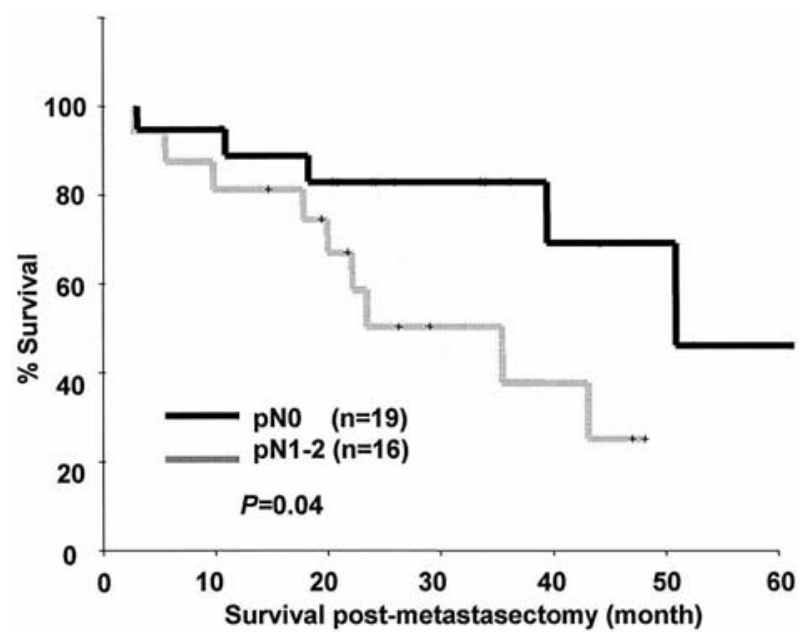

Fig. 3 Survival rates according to the pathologic N factor $(\mathrm{pN})$. 


\section{考察}

非小細胞肺癌は病理病期 I 期においても30〜40\%が 術後再発を来たし, その内約 $70 \%$ は脳, 肺, 肝, 副腎 などへの遠隔転移である5)。したがって，それらがす でに潜在的に全身多発転移を伴うものであるとする考 えは極めて妥当であり, 主たる治療法としては全身化 学療法が選択されなければならない.しかし治療成績 は極めて不良と言わざるを得ず，MST は 1 年を越え ない6)，一方，遠隔転移の中にも゙全身播種には至らず， 限られた臓器に少数個のみの転移を来す”という oligometastasis の概念が存在し，この場合，遠隔転移 巣に対する積極的な局所治療が根治までには至らずと も, 予後の延長を獲得し得るのではないかという仮説 が成り立つ7). Yoshino らは非小細胞肺癌完全切除後 の遠隔転移118症例を多変量解析した結果, “転移巣切 除”が有意な予後因子の一つであったとし, 完全切除 が可能であるならばそれは予後延長を期待できる有効 な治療手段になり得ると結論付けている ${ }^{8)}$. しかしど のような症例がその適応になるかは未だ明確には示し 得ていない.

遠隔転移の中でも, 脳転移においては局所治療の対 象となる症例が存在する。 これまでに多くの症例研究, 比較研究がなされ, 単発あるいは多くとも 4 個以内の 転移巣に対しては, 局所効果や QOL, 生存期間におい て，外科切除や SRSの有意性がすでに証明されてい

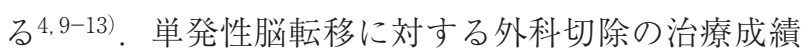
は 2 年生存率 $24-41 \%, 5$ 年生存率11-21\%, MST が 11-24カ月であり, それらの予後因子解析によって, 原 発巣の完全切除, リンパ節転移なし, 他臓器転移なし, テント上への転移, 腺癌などの因子を有する集団が予 後良好であることも明らかとなっている。 また単発性 副腎転移に対する外科切除の報告も比較的多く存在

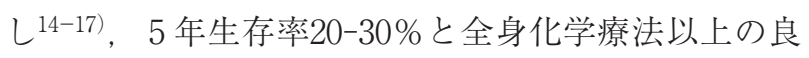
好な治療成績が得られている。 そして転移までの無 病期間が 6 カ月以上であるものやリンパ節転移を認め ない症例に長期予後が期待できるとしている。このよ うな背景から, 総じて, 脳以外の部位に対する転移巣 切除においても, 少なくとも以下の条件を満たす集団 が手術適応として許容されるのではないかと推察され る. (a)原発巣が完全切除されている, (b) 転移巣は単一 臓器に少数個以内である, (C) 原発巣病期は early stage
である。

今回我々は上述の適応基準の想定に基づいた retrospective な症例集積を行い, 遠隔転移巣に対する 外科治療の成績を検討した。全体として転移巣術後 2 年生存率 $68.0 \%, \mathrm{MST} 43.1$ 力 と十分満足のいく結果 となり，少なくとも我々が設定した適格基準を満たす 症例に抏いては, その有効性が示されたものと判断す る。また原発巣 $\mathrm{pN} 0$ 症例が有意に良好な予後が望め ることも判明した。脳転移においては再発10例中 7 例 が新たな脳転移を来したものの, 内 4 例は開頭切除,

SRS をさらに追加施行することにより1000日以上もの 長期生存を達し得ている。副腎転移では 2 年生存率 $55.6 \%$ とこれまでの報告と遜色のないものであったが, 再発 4 例中 3 例に腹腔内局所再発を認めた。 いずれも pN1-2 症例であることから術前には腹腔内リンパ系播 種も想定した慎重な全身検索が必要と考えられた。肺 転移では部分切除が 9 例, 残存肺全摘術が 1 例行われ, 2 年生存率 $78.7 \%$ と極めて良好な結果を示した。ただ し, これらが再発経過, CT 所見, 病理所見などの総合 的臨床判断により転移と見なし切除された症例ではあ るものの, 10 例中 8 例が $\mathrm{pN} 0$ 症例であることから多発 肺癌をも含んだ予後結果であるとの解釈も当然必要で あろう。術式に関しては術前に多発癌と再発癌との鑑 別が極めて困難であるために双方を考慮した術式選択 が必要と言える。根治性を優先し機能的に耐術である ならば肺葉切除を第一選択とすべきであるが，3次癌 や再発癌切除後の補助療法を考慮した場合, リンパ節 転移の評価や腫瘍局在, 大きさなどにおいて適応と判 断されるのであれば, 呼吸機能を温存した縮小手術を 行うことがより妥当であると我々は考える。

今回の検討で対象とした症例は, 適格基準が示すよ うに極めて biasのかかった集団であり，得られた結果 は“転移巣手術をすればよりよい予後が得られるので はないかと期待できる症例” での予後を見たものとも 言える。これは逆の見方をすれば, 外科治療の意義が 見い出せる症例はそのようにして選択された集団の中 に存在するという証明でもある. 現在我々はその検証 を行うべく prospective な trial を進行中である.

\section{結語}

原発性非小細胞肺癌完全切除例の単発あるいは少数 個の遠隔転移巣に対する外科治療成績を検討した，外 
科治療の有効性はリンパ節転移を認めない原発肺癌早 期症例において存在し, その予後の向上に寄与する可 能性が示唆された。

\section{文献}

1）日本肺癌学会編：EBM の手法による肺癌診療ガイドラ イン. 2005年版. 東京 ; 金原出版, 2005: p160-162.

2) Luketich JD, Martini N, Ginsberg RJ, et al. Successful treatment of solitary extracranial metastases form nonsmall cell lung cancer. Ann Thorac Surg 1995; 60: 16091611.

3) Ambrogi V, Tonini G, Mineo TC. Prolonged survival after extracranial metastasectomy from synchronous respectable lung cancer. Ann Surg Oncol 2001; 8: 663-666.

4) Aucher RM, Lamond JP, Alexander E, et al. A multiinstitutional outcome and prognostic factor analysis of radiosurgery for respectable solitary brain metastasis. Int J Radiat Oncol Biol Phys 1996; 35: 27-35.

5) Martini N, Bains MS, Burt ME, et al. Incidence of local recurrence and second primary tumors in resected stage I lung cancer. J Thorac Cardiovasc Surg 1995; 109: 120129.

6) Walsh GL, O'Connor M, Willis KM, et al. Is follow-up of lung cancer patients after resection medically indicated and cost- effective?. Ann Thorac Surg 1995; 60: 15631572 .

7) Hellman S, Wichselbaum RR. Oligometastases. J Clin Oncol 1995; 13: 8-10.

8) Yoshino I, Nakanishi R, Osaki T, et al. Postoperative prognosis in patients with non-small cell lung cancer with synchronaous ipsilateral intrapulmonary metastasis. Ann Thorac Surg 1997; 64: 809-813.
9) Wronski M, Arbit E, Burt M, Galicich JH. Survival after surgical treatment of brain metastases from lung cancer. a follow-up study of 231 patients treated between 1976 and 1991. J Neurosurg 1995 83: 605-616.

10) Mussi A, Pistolesi M, Lucchi M, Janni A, Chella A, Parenti G, et al. Resection of single brain metastasis in non-small-cell lung cancer: prognostic factors. J Thorac Cardiovasc Surg 1996; 112: 146-53.

11) Billing PS, Miller DL, Allen MS, Deschamps C, Trastek VF, Pairolero PC. Surgical treatment of primary lung cancer with synchronous brain metastases. J Thorac Cardiovasc Surg 2001; 122: 548-553.

12) Bonnette P, Puyo P, Gabriel C, Giudicelli R, Regnard JF, Riquet M, et al. Surgical management of non-small cell lung cancer with synchronous brain metastases. Chest 2001; 119: 1469-1475.

13) Granone P, Margaritora S, D'Andrilli A, Cesario A, Kawamukai K, Meacci E. Non-small cell lung cancer with single brain metastasis: the role of surgical treatment. Eur J Cardio-Thorac Surg 2001; 20: 361-366.

14) Luketich JD, Burt ME. Does resection of adrenal metastases from non-small cell lung cancer improve survival?. Ann Thorac Surg 1996; 62: 1614-1616.

15) Kim SH, Brennan MF, Russo P, et al. The role of surgery in the treatment of clinically isolated adrenal matastasis. Cancer 1998; 82: 389-394.

16) Mercier $O$, Fadel E, de Perrot $M$, et al. Surgical treatment of solitary adrenal metastasis from non-small cell lung cancer, J Thorac Cardiovasc Surg 2005; 130: 136-140.

17) Ito $S$, Imai $T$, Usami $N$, et al. Surgical treatment for adrenal metastasis from lung cancer. Kyobu Geka 2006; 59: $47-52$. 


\title{
Assessment of surgical treatment for distant metastasis from completely resected non-small cell lung cancer
}

\author{
Tohru Hasumi*1, Nobuyuki Sato*2, Shinichirou Ohta*3, Masami Sato*4, Chiaki Endo*5 \\ Takashi Kondo*5, Hiroyuki Suzuki*6, Hiroyuki Oizumi*7, Masayuki Chida*8 \\ Takao Tsushima*9, Tsutomu Sakuma*10, Yasuki Saito*1 \\ ${ }^{* 1}$ Department of Thoracic Surgery, Sendai Medical Center \\ ${ }^{* 2}$ Department of Thoracic Surgery, Aomori Prefectural Hospital \\ ${ }^{*}$ Department of Thoracic Surgery, Shizuoka General Hospital \\ ${ }^{*}$ Division of Thoracic Surgery, Miyagi Cancer Center \\ ${ }^{*}$ Department of Thoracic Surgery, Institute of Development, Aging and Cancer, Tohoku University \\ ${ }^{*}$ Department of Surgery I, Fukushima Medical University \\ ${ }^{* 7}$ Department of Cardiovascular, Thoracic and Pediatric surgery, Yamagata University School of Medicine \\ ${ }^{* 8}$ Department of Thoracic Surgery, Ohta-Nishinouchi Hospital \\ ${ }^{* 9}$ Department of General Thoracic Surgery and Cardiovascular Surgery, Hirosaki University Hospital \\ ${ }^{* 10}$ Department of Thoracic Surgery, Kanazawa Medical University
}

Background: In recent case reports and limited series, long-term survival has been reported after surgical treatment of a solitary distant metastasis from non-small cell lung cancer (NSCLC). However, the role and indications of surgical resection are still unclear. Our aim is to investigate the prognosis of patients after resection of distant metastases in various sites and to identify characteristics of patients who achieve prolonged survival. Patients and Methods: We retrospectively reviewed patients who had undergone surgical treatments for distant NSCLC metastasis between January 1998 and December 2003, according to the following criteria: primary NSCLC that was completely resected, and distant metastasis that was a solitary (or few) lesion, synchronously or metachronously diagnosed. Results: Thirty-five patients entered the study. Metastasectomy was performed for the following sites: brain ( $\mathrm{n}=17$ ), lung $(n=10)$, adrenal gland $(n=6)$, and chest wall $(n=2)$. Other profiles of metastases were the following: synchronous ( $n=6$, all in the brain), metachronous $(n=29)$, solitary $(n=30)$, and $2-3$ lesions ( $n=5$, all in the brain). The overall median survival time (MST) after metastasectomy was 43.1months, and the 2-year survival rate was $68.0 \%$. According to the provisional pathologic stage, excluding the $\mathrm{M}$ factor, of the primary tumor, 2-year survival rates of stage I ( $\mathrm{n}=16$ ), II $(\mathrm{n}=14)$, and III $(\mathrm{n}=5)$ were $86.5 \%, 53.0 \%$, and 60.0\%, respectively. Concerning thoracic lymph node metastasis, patients with pN0 status had a 82.9\% 2-year survival (MST: 50.9months) and significantly prolonged survival compared to patients with pN1-2 status (2-year survival: 50.3\%, MST: 35.4months). Conclusions: This study suggested that surgical treatment for oligometastatic disease could be considered as an arm of multi-modal therapy in selected patients with early stage primary NSCLC and no lymph node metastases, and might prolong the survival in such cases. 